\title{
Molecular Methods for Bacterial Strain Typing
}

Leili Shokoohizadeh(PhD)

Department of Laboratory Medical

Sciences, Faculty of Para Medical

Sciences, Ahvaz Jundishapur

University of Medical Sciences,

Ahvaz, Iran

Corresponding Author: Leil Shokoohizadeh

Email: shokoohizadeh-L@ajums.ac.ir Tel: +989183885309

Adderess: , Faculty of Para Medical Sciences, Ahvaz Jundishapur University of Medical Sciences, Ahvaz, Iran

Received : 05 Nov 2014

Revised: 08 Feb 2015

Accepted: 14 Feb 2015

\section{ABSTRACT}

Typing of bacteria is an important part of epidemiological studies on nosocomial infections. Bacterial identification methods have dramatically improved in recent years, which is mainly due to advancements in the field of molecular biotechnology. In many cases, molecular techniques have replaced phenotypic typing methods.

Currently, a wide range of bacterial typing techniques is used that are different from one another in the aspects of study objectives, costs, reliability and discriminatory power. None of the typing methods can achieve all desired objectives of a study alone.

Different typing methods are used for various purposes including: l. confirmation of epidemiological relationships in spread of an infection, 2. providing epidemiological hypotheses about epidemiological relationships between bacteria in the absence of epidemiological data, 3. describing the distribution of bacterial types and identification of affecting factors. Inferences of epidemiological studies depend on the chosen typing technique and objectives of the study.

Therefore, the typing technique can be useful and effective in increasing our understanding of the pathogenesis, transmission and prevention of possible diseases. The aim of this study was to evaluate various methods of molecular typing of bacteria and to compare these methods from different aspects.

Keywords: Molecular, Molecular Typing, Bacterium. 


\section{INTRODUCTION}

The outbreak of nosocomial infections are continually being reported around the world (1). Although fungi, viruses and parasites can also cause nosocomial infections, the most common cause is bacterial agents (1). The use of therapeutic tools such as ventilator, catheter and other equipment in hospitals and patients themselves are considered as sources of infection (2). In addition, the reduced effectiveness of antibiotics due to emergence of resistant bacteria has made controlling the spread of bacterial infections very difficult (3). To investigate the prevalence of bacterial infections in hospitals, the data obtained from bacterial strain typing are needed to identify the type of bacteria at the strain level and to distinguish epidemic isolates from endemic and sporadic isolates $(4,5)$. The results of bacterial strain typing using new molecular methods will be effective and helpful for evaluating the prevalence of a wide range of pathogens such as methicillin-resistant Staphylococcus aureus (MRSA), vancomycinresistant Enterococci (VRE), Pseudomonas aeruginosa, Klebsiella pneumoniae and other bacteria $(6,7,8)$. The objectives of bacterial typing generally include control of communicable diseases, identification of origin, transmission mechanisms and the rate of infection spread. Moreover, molecular typing technology can exceed the objectives: determining the dynamics and genetics of bacterial populations, ecological studies to identify and monitor new microorganisms in new habitats, and new industrial plans to search for new bacterial products to deal with bioterrorism $(9,10)$. Generally, typing of bacteria is based on their phenotypic and genotypic characteristics (11). In the past, classification and identification of bacteria were based on their phenotypic characterization using techniques such as serological, biochemical and phage typing as well as antibiotic sensitivity testing. However, these tests have a number of shortcomings including: some of these tests are for the identification of a group of bacteria and cannot be used for other groups, the procedure is time-consuming and only used for a limited range of bacterial species $(6,12)$.
Therefore, there is a need for comprehensive molecular approaches for quicker identification and typing and more power of discrimination. Nucleic acids, proteins and lipopolysaccharides contain sufficient information in their sequences in this regard. Overall, typing of bacteria for identification of bacterial strains is performed as two methods of epityping for epidemiological purposes and pathotyping to monitor the potential virulence of bacteria (13). This study represents an overview of the molecular typing methods based on nucleic acids. The methods based on nucleic acid analysis and bacterial genome could be around two main axes including:

1. Evaluating the association of nucleic acid molecules, their structure and size. Nucleic acids can be analyzed by means of four methods or four different targets.
a. Plasmid DNA analysis
b. Chromosomal DNA analysis
c. Hybridization
d. Amplification (PCR) and sequencing $(14,15)$

\section{MATERIAL AND METHODS}

Plasmid DNA analysis

Study of plasmid patterns is among the simplest targets of investigating bacterial nucleic acids and one of the first molecular methods of bacterial typing (16).

Nowadays, the simple plasmid patterns can be used for typing different bacterial genera. The strains can be identified based on the number and size of plasmids. It is also used to investigate antimicrobial susceptibility in clinical microbiology laboratories.

Using this technique, the prevalence of nosocomial and community-acquired infections caused by different Gram-negative bacilli can be successfully analyzed. Enzyme digestion using restriction enzymes or endonuclease to create DNA fingerprints (in form of linear DNA fragments) can also be used for further analysis of plasmid DNA, especially large plasmids. DNA fragments can be compared by DNA-DNA hybridization. The flaws of using plasmid DNA include lack of durability and stability of plasmids in some bacterial strains and lack of efficiency in the strains that lack the desired plasmids (17-19). 
Bacterial chromosome is a large and fragile molecule. Recently, some methods have been developed that can place intact cells in agarose plugs and perform lysis and deproteinization on bacterial strains within the plug.

After treatment by appropriate endonuclease enzymes, agarose plugs containing the sample can be placed directly into agarose gel well for electrophoresis. The conventional agarose gel techniques do not allow the separation of DNA fragments larger than $50 \mathrm{Kbp}$ and the restriction enzymes produce many similar fragments. This problem is solved by the pulsed-field electrophoresis technique (PFGE)(20).

The PFGE technique was first described by Schwartz and Cantor in 1984. They were able to separate successfully thousands of Kbp long yeast chromosome.

The technique uses endonuclease enzymes that cut genomic DNA in the limited regions and thus create small number of fragments (10 to 20 fragments).

The results are analyzed and interpreted based on comparison of the created bands' patterns related to each sample. Although all bacterial species could be typed using this technique, it makes the separation of chromosomal DNA difficult in some bacterial strains. For example, chromosomal DNA of some strains of Clostridium difficile is cutoff on its own and the use of this technique is not possible.

The PFGE enables the migration of distinct fragments in a large electric field.

There are several types of this technique based on the form of pulsed electric field. The most common type is clamped homogeneous electric field (CHEF) that spreads the electric current uniformly across the entire field $(21,22)$.

This technique has been successful in subtyping of many pathogenic bacteria. A wide range of Gram-positive and Gramnegative bacteria and mycobacteria have been typed using the PFGE technique, thus it can be used as a general technique for this purpose $(23,24)$.

http://www.cdc.gov.net database is available for a large number of bacteria that have been studied by this method.
This method has a higher discriminatory power for many bacteria in comparison with the other typing methods.

The bands resulted from DNA cutting by restriction enzymes are stable and reproducible in laboratories, and even between laboratories $(11,22)$.

Limitations of PFGE

It is time-consuming: the procedure of this technique is different depending on the specie of bacteria, but overall the sample preparation, electrophoresis and detection of the bands require several days.

It requires a high level of individual skills and an expert with a lot of experience and expertise.

The band patterns obtained by a technician could be different from the results of the same samples reported by other technicians.

It is not possible to claim that the bands of the same size definitely belong to the same DNA fragment.

It is impossible to optimize separation of the bands from any part of the gel.

Changes in an enzyme restriction site can lead to more than one change in the bands created. In fact, bands and not sequences, they are just the bands. Similar bands may not necessarily belong to the same DNA fragments (11).

\section{Hybridization}

Hybridization is considered a routine technique for detection of presence or absence of certain bacterial species in clinical and environmental samples using specific nucleic acid probes.

1.Separation of fragments from chromosomal DNA using endonuclease enzymes on agarose gel

2.Transferring to a nylon or nitrocellulose membrane

3.Hybridization with labeled probes

4.Detection by placing a photographic film placed on the nitrocellulose membrane so that the membrane is exposed to radioactive substance and bands becomes apparent.

Ribotyping is one of the most common and widely used methods based on hybridization. In this technique, ribosomal RNA (rRNA) genes and genes associated with RNA are used as probes $(22,25)$. 
Advantages of the ribotyping technique

1. It is applicable for a wide range of microorganisms.

2. Commercially available rRNA probes can be used as general probes.

3. Hybridization patterns are reproducible and interpreted easily.

4. Created band patterns can be compared using computer analyzes and stored on databases.

\section{Limitations of the ribotyping technique}

1.It is time consuming and somewhat complex. 2.Information can only be obtained from the certain regions of the genome that have been hybridized with the probe $(26,27)$.

\section{Typing based on PCR}

The most important typing techniques based on PCR includes:

1.RFLP analysis: Restriction fragment length polymorphism created by PCR using specific primers

2.AFLP: amplification of polymorphic restricted ploymorphed fragments

3.PCR ribotyping

4.Repetitive sequence-based PCR (Rep-PCR)

5.Randomly amplified polymorphic DNA fingerprinting (RAPD-PCR) $(28,29)$

\section{RFLP}

This method is based on the enzymatic digestion of amplified DNA using endonuclease enzymes in order to produce RFLPs and compare band patterns. This method requires less time, because the hybridization phase is removed (30).

\section{AFLP}

Two endonuclease enzymes are used in the method that attach to the end of restriction fragments of an adapter. Then, PCR is done using the primers complementary to the adapter and restriction fragments. The presence or absence of fragments is defined as fingerprint or an AFLP pattern. This technique is used to perform a variety of purposes including typing, molecular markers identification, mapping of genetic loci and evaluation of genetic diversity (31).

\section{PCR ribotyping}

This technique was described earlier, but there are some alternatives to this method involving the use of PCR to determine polymorphisms in genes or intergenic regions associated with
rRNA or tRNA. Production of large number of rRNA copies by PCR increases the sensitivity of the method for diagnosis (32).

\section{Rep-PCR}

It is an alternative technique for producing fingerprints directly and without the use of endonuclease enzymes. The oligonucleotide primers are designed based on repetitive nucleotide sequences in prokaryotes.

This technique is rapid, reproducible and has a high discriminatory power. Three types of primers are used in this method with sequences that are complementary to three types of repetitive elements: one titled ERIC (126 bp long) is complementary to repetitive intergenic sequences of the family Enterobacteriaceae and another called REP (38 bp long) is complementary to extragenic palindromic sequences. Third region is the 154-bp BOX element (34).

\section{RAPD-PCR}

Random amplified polymorphic DNA (RAPD) technique is also known as arbitrary primed PCR (AP-PCR), due to amplification of unnamed regions of the genome.

In this method, the primers with short lengths (usually $10 \mathrm{bp}$ and sometimes longer or shorter than $10 \mathrm{bp}$ ) are used. Usually, a certain type of primer is used for each reaction, but two primers could also be used in some cases. In addition, random primers are usually used.

The annealing temperature is low (about 35 to $40{ }^{\circ} \mathrm{C}$ ), but it can be increased in order to increase the specificity of the reaction. The number of bands is related to size of the target genome, primer length and the annealing temperature. The bands created in this method are less than $2 \mathrm{Kbp}$ in length (36).

\section{Advantages of RAPD}

1.low costs for testing

2.Requires small amounts of DNA

3.Easily done and not technically difficult

4.No need for previous information about the genome

5.Can show genetic diversity in all organisms

\section{Disadvantage of RAPD}

1.There is a problem in reproduction of results. 2.It is not technically very strong and is largely affected by environmental conditions.

3.Presence of negative or null alleles in all cases is not related to an identical mutation $(34,36)$. 


\section{Typing based on nucleic acids sequencing}

The conserved genes are in the stable conditions in all organisms. The best-known and most specific method for identifying and typing of organisms is to determine the exact nucleotide sequence of certain regions in their chromosomes that are normally conserved.

In the past, nucleotide sequencing was done using chemical method (Maxam and Gilbert) and Sanger sequencing that had the following problems. These methods were timeconsuming and complex in nature. There was very small amount of target material in the sample and the Sanger method required cloning step (37).

Fortunately, the PCR method provides the possibility to produce large amounts of template material for sequencing of a locus in the genomic DNA. Accordingly, there are various methods for sequencing-based typing and the most important of them include:

1.Multilocus variable-number tandem repeat analysis (MLVA)

2.Multilocus sequence typing (MLST)

3.Whole genome sequencing

MLVA

The genome of many bacteria contains the regions of variable number tandem repeat (VNTR) that could be from a few bp to more than 100bp in length.

In fact, MLVA is typing of bacteria based on the number of VNTRs. These sequences are genetically very unstable.

The results depend on the type and number of repetitive loci. In the MLVA technique, number of copies resulted from each of these repetitive loci are classified together and placed in the same category. The number of repetitions in variable sequences could be variable in strains of bacterial specie.
This method not only shows the changes in the variable sequences but also provide a catalog of changes (point mutations, deletions and insertions) at these repetitive sequences. The method is useful for clinical microbiology, typing and phylogenetic and dynamic evaluation of bacteria $(38,39)$.

\section{MLST}

This method is widely used for phylogenetic studies and typing of bacteria. The method is based on PCR and sequencing of fragments within a number of (six to seven) housekeeping genes in the entire bacterial chromosome. The difference between allelic patterns is defined as sequence type (ST).

The genetic relationship between isolates is determined by comparing STs. Recent studies have shown that the MLST can be used to determine the most common nosocomial pathogens, especially during outbreaks. Moreover, it can be used indirectly to identify the host that the bacteria have been isolated from and to determine host susceptibility to infection or colonization by a specific clone or genotype of bacteria. A database (http://pubmlst.org) is designed that provides updated information for a lot of bacteria (3941).

\section{Whole genome sequencing}

It is a definitive resource for studying genetic diversity of bacteria, which shows mutations in the whole genome (42).

\section{DNA array}

This technique is based on obtaining the differences between bacterial isolates by genomic DNA hybridization with synthetic DNA. This technique is mostly used to identify the fragments of the genome with no complementary sequences available for them (43).

Table 1- Comparison of the most important and widely used bacterial typing techniques

\begin{tabular}{|c|c|c|c|c|c|c|}
\hline $\begin{array}{c}\text { Typing } \\
\text { techniques }\end{array}$ & $\begin{array}{c}\text { Discriminatory } \\
\text { power }\end{array}$ & Repeatability & Reproducibility & $\begin{array}{c}\text { Diffused or } \\
\text { limited to } \\
\text { certain parts of } \\
\text { the genome } \\
\end{array}$ & $\begin{array}{l}\text { Time required } \\
\text { after culture }\end{array}$ & $\begin{array}{c}\text { Cost and } \\
\text { equipment }\end{array}$ \\
\hline PFGE & $\begin{array}{c}\text { Moderate to } \\
\text { high }\end{array}$ & $\begin{array}{c}\text { Moderate to } \\
\text { high }\end{array}$ & $\begin{array}{c}\text { Moderate to } \\
\text { high }\end{array}$ & Diffused & 3 days & $\begin{array}{l}\text { High equipment } \\
\text { and facilities }\end{array}$ \\
\hline RFLP & $\begin{array}{c}\text { Moderate to } \\
\text { high }\end{array}$ & $\begin{array}{c}\text { Moderate to } \\
\text { high }\end{array}$ & Moderate & Diffused & 1-3 days & Moderate \\
\hline AFLP & $\begin{array}{l}\text { Moderate to } \\
\text { high }\end{array}$ & High & $\begin{array}{c}\text { Moderate to } \\
\text { high }\end{array}$ & Diffused & 2 days & Moderate \\
\hline Plasmid profile & Low & High & Moderate & Limited & 1 day & Low \\
\hline RAPD & Low & Low & Moderate & Diffused & 1 day & Low \\
\hline REP & Low to moderate & Moderate & Low & Diffused & 1 day & Low \\
\hline MLST & $\begin{array}{l}\text { Moderate to } \\
\text { high }\end{array}$ & High & High & Diffused & 1 day & $\begin{array}{c}\text { Moderate to } \\
\text { high }\end{array}$ \\
\hline MLVA & $\begin{array}{l}\text { Moderate to } \\
\text { high }\end{array}$ & $\begin{array}{c}\text { Moderate to } \\
\text { high }\end{array}$ & $\begin{array}{c}\text { Moderate to } \\
\text { high }\end{array}$ & Diffused & 1 day & $\begin{array}{c}\text { Moderate to } \\
\text { high }\end{array}$ \\
\hline $\begin{array}{l}\text { Sequencing } \\
\text { whole genome }\end{array}$ & High & High & High & Whole genome & $\begin{array}{c}\text { Several months } \\
\text { and years }\end{array}$ & $\begin{array}{c}\text { Moderate to } \\
\text { high }\end{array}$ \\
\hline DNA array & High & $\begin{array}{c}\text { Moderate to } \\
\text { high }\end{array}$ & $\begin{array}{c}\text { Moderate to } \\
\text { high }\end{array}$ & Diffused & $\begin{array}{l}\text { Several weeks } \\
\text { and months }\end{array}$ & High \\
\hline
\end{tabular}




\section{CONCLUSION}

The relationship between bacterial isolates in an outbreak, and methods of spread and transmission of bacterial infections can be determined using molecular typing methods. Bacterial typing is performed at different levels ranging from local studies in hospitals or other basic laboratories to regional and national studies in reference laboratory. Typing methods provide useful information about epidemiological surveillance of infectious diseases. The information includes data collection process, analysis, interpretation of results, consequences of spread and transmission of infection, process of infection

\section{REFERENCES}

1. Emori TG, Gynes RP. An overview of nosocomial infections, including the role of the microbiology laboratory. Clin Microbiol Rev. 1993; 6(4): 428-442.

2. Olive KE, Berk SI. Infection in the nursing home. Clin Geriatr Med. 1992; 8(4): 821-834. PMID:1423137.

3. Maki DG, Rhame FS, Mackel DC, Bennet JV. Nationwide epidemic of septicemia caused by contaminated intravenous products. I. Epidemiologic and clinical features. Am J Med. 1976; 60(4): 471-485.

4. Tenover FC, Hughes JM. The challenges of emerging infectious diseases. Development and spread of multiplyresistant bacterial pathogens. JAMA. 1996; 275(4): 300304.

5. Boyle JF, Soumakis SA, Rendo A, Herrington JA, Gianarkis DG, Thurberg BE, et al. Epidemiologic analysis and genotypic characterization of a nosocomial outbreak of vancomycin-resistant enterococci. J Clin Microbiol. 1993; 31(5): 1280-5.

6. Arbeit RD. laboratory procedure for the epidemiologic analysis for microorganism. Manual of Clinical Microbiology. $6^{\text {th }}$ ed, Washington DC: American Society for Microbiology. 1995; 105-208.

7. Mehndiratta PL, Bhalla P. Typing of Methicillin resistant Staphylococcus aureus: A technical review. Indian J med Microbiol. 2012; 30(1): 16-23. doi: 10.4103/0255-0857.93015.

8. Montecalvo MA, Horowitz H, Gedris C, Carbonaro C, Tenover FC, Issah A, et al. Outbreak of vancomycin-, ampicillin-, and aminoglycoside-resistant Enterococcus faecium bacteremia in an adult oncology unit. Antimicrob Agent Chemother. 1994; 38(6): 1363-1367.

9. Lessig R, Zoledziewska M, Fahr K, Edellman J, Kostrzewa M, Dobosz T, et al. Y-SNP-genotyping: a new approach in forensic analysis. Forensic Sci Int. 2005; 154(2-3): 128-136.

10. Tibayrenc M. Towards a unified evolutionary genetics of microorganisms. Annu Rev Microbiol. 1996; 50: 401-429.

11. Tenover FC, Arbeit RD, Goering RV, Mickelsen $\mathrm{PA}$, Murray $\mathrm{BE}$, Persing $\mathrm{DH}$, et al. Interpreting chromosomal DNA restriction patterns produced by pulsed-field gel electrophoresis: criteria for bacterial strain typing. J Clin MIcrbiol. 1995; 33(9): 2233-2239. and designing strategies to limit the spread of infection in hospitals and community. Typing methods are not efficient when used alone, and interpretation of their results requires epidemiological, clinical and demographic data. Therefore, Epidemiologists should cooperate with other laboratories to choose the best technique for typing and interpretation of results. Regarding the use of each typing technique, one should always pay attention to the costs, reproducibility, reliability, discriminatory power between bacterial strains, and eventually to objectives of typing.

13. van Belkum A, Tassios PT, Dijkshoorn L, Haeggman $\mathrm{S}$, Cookson $\mathrm{B}$, Fry $\mathrm{NK}$, et al. Guidelines for the validation and application of typing methods for use in bacterial epidemiology. Clin Microbiol Infect. 2007; 13(3): 1-46.

14. Singh A, Goering RV, Simjee S, Foley SL, Zervos MJ. Application of molecular techniques to the study of hospital infection. Clin Microbiol Rev. 2006; 19(3): 512-530.

15. Towner KJ, Cockkayne E. Molecular methods for microbial identification typing. $1^{\text {st }}$ ed Chapman \& Hall, Ltd. London, England; 1995; 3-10.

16. Schaberg DR, Tompkins LS. Falkow S. Use of agarose gel electerophoresis of plasmid deoxyribonucleic acid to fingerprint gram negative bacilli. J Clin Microbiol. 1981; 13(6): 1105-1110.

17. Wei ZQ, Chen YG, Yu YS, Lu WX, Li LJ. Nosocomial spread of multi-resistant Klebsiella pneumoniae containinga plasmid encoding multiple betalactamases. J Med Microbiol. 2005; 54(9): 885-888.

18. Crawford JT. Genotyping in contact investigations: a CDC perspective. Int J Tuberc Lung Dis. 2003; 7(12): 453-7.

19. Pang JC, Chiu TH, Chiou CS, Schroeter A, Guerra $\mathrm{B}$, Helmuth R, et al. Pulsed field gel electrophoresis,plasmid profiles and phage types for the human isolates of Salmonella enterica serovar enteritidis obtained over 13 years in Taiwan. J Appl Microbiol. 2005; 99(6): 1472-1483.

20. Beadle J, Wright M, NcNeely L, Bennett JW. Electrophoretic karyotype analysis in fungi. Adv Appl Microbiol. 2003; 53: 243-270.

21. Wagner L, Lai E. Separation of large DNA molecules with high voltage pulsed field gel electrophoresis. Electrophoresis. 1994; 15(8-9): 1078-1083.

22. Southern EM. Detection of specific sequences among DNA fragments separated by gel electrophoresis. J Mol Biol. 1975; 98(3): 503-517.

12. Swaminthan B, Matar GM. Molecular typing methods: definition, application and advantages. Washington DC, American Society for Microbiology. 1993: 26-50. 
23. Shokoohizadeh L, Mobarez AM, Zali MR, Ranjbar $\mathrm{R}$, Alebouyeh M, Sakinc $\mathrm{T}$, et al. High frequency distribution of heterogeneous vancomycin resistant Enterococcous faecium (VREfm) in Iranian hospitals. Diagnostic pathology. 2013; 8(1): 163.

24. Shokoohizadeh L, Zali M R, Mobarez A, Alebouye M, Ranjbar R, Ahmadi Z. Antibiotic Resistance and Genotypic Characterization of MDR Enterococcusfaecium Isolates from Clinical and Hospital Environmental Samples by PFGE in Tehran,Iran. Iranian J Med Sci: Shiraz, 2012; 37(3): P24.

25. Van Leeuwen WB, Verbrugh HA, Van der Velden J, Van Leeuwen N, Heck M, Van Belkum A. Validation of binary typing for Staphylococcus aureus strains. J Clin Microbiol. 1999; 37(3): 664-674.

26. Stull TM, Lipuma JJ, Edlind TD. A broad spectrum for molecular epidemiology of bacteria: ribosomal RNA. J Infect Dis. 1988; 157(2): 280-286.

27. Gordillo ME, Singh KV, Murray BE. Comparison of ribotyping and pulsed-field gel electerophoresis for subspecies differentiation of strain of enterococcus faecalis. J Clin Microbio. 1993; 31(6): 1570-1574.

28. Van Belkum A. DNA fingerprinting of medically important microorganism by use of PCR. Clin Microbiol Rev. 1994; 7(2): 174-184.

29. Welsh J, Mc Celland M. fingerprinting genome using PCR with arbitrary primers. Nucleic Acid Res. 1990; 18(24): 7213-7218.

30. Owen RJ. Chromosomal DNA fingerprinting: a new method of species and strain identification applicable to microbial pathogens. J Med Microbiol. 1989; 30: 89-99.

31. Klaassen CH, van Haren HA, Horrevorts AM.

Molecular fingerprinting of Clostridium difficile isolates: pulsed-field gel electrophoresis versus amplified fragment length polymorphism. J clin microbiol. 2002 1; 40(1):101-4. PMID: 11773100

32. Grimont F, Grimont PAD. Ribosomal nucleic acid gene restriction pattern as potential taxonomic tools. Ann Inst Pasteur Microbiol. 1986; 137 (2): 165-75.

33. Hiett $\mathrm{KL}$, Seal Bs. Use of repetitive element palindormic PCR (rep-PCR) for the epidemiologic discrimination of food borne pathogens. Method Microbiol. 2009; 551:49-58.

34. van Belkum A, Klutymans J, van Leeuwen W, Bax R, Quint W, Peters E, et al. Multi-center evaluation of arbitrarily primed PCR for typing of Staphylo-coccus aureus strains. J Clin Microbiol. 1995, 33, 1537-1547. PMCID: PMC228211.
35. Tyler KD, Wang G, Tyler SD, Johnson WM. Factor affecting reliability and reproducibility of amplificationbased DNA fingerprinting of representative bacterial pathogen. J Clin Microbial. 1997; 35(2): 339-346.

36. DuBose RF, dykhuiszen DE, Hartl DL. Genetic exchange among natural isolates of bacteria recombination within the pho A gene Escherichia coli. Proc Natl Acad Sci USA. 1988; 85: 7036-740.

37. Danin-Poleg Y, Cohen LA, Gancz H, Broza YY, Goldshmidt H, Malul E,. Vibrio cholerae strain typing and phylogeny study based on simple sequence repeats. $J$ Clin Microbiol 2007; 45:736-746.

38. Van Belkum A. Tracing isolates of bacterial species by multilocus variable number of tandem repeat analysis (MLVA). FEMS Immunol Med Microbiol. 2007; 49(1): 22-27.

39. Maiden MC, Bygraves JA, Feil E, Morelli G, Russell JE, Urwin R, et al. Multilocus sequence typing: a portable approach to the identification of clones within populations of pathogenic microorganisms. Proceedings of the National Academy of Sciences. 1998; 95(6): 31403145.

40. Shokoohizadeh L. Dominant clones of MDR Enterococcus faecium among clinical isolates by pulsed-field gel electrophoresis (PFGE) and multi locus sequence typing (MLST). $\mathrm{PhD}$ thesis, Tarbiat Modares University, 2013.

41. McCarthy ND. Colles FM, Dingle KE, Bagnall MC, Manning G, Miaden MCJ, et al. Host-associated genetic import in Campylobacter jejuni. Emerg Infect Dis. 2007; 13(2): 267-272.

42. Mwangi MM, Wu SW, Zhou Y, Sieradzki K, de Lencastre H, Richardson $\mathrm{P}$, et al. Tracking the in vivo evolution of multidrug resistance in Staphylococcus aureus by whole genome sequencing. Proc Natl Acad Sci USA 2007; 104(22): 9451-9456.

43. El-Adawy H, Hotzel H, Tomaso H, Neubauer H, Taboada EN, Ehricht R, et al. Detection of genetic diversity in Campylobacter jejuni isolated from a commercial turkey flock using flaA typing, MLST analysis and microarray assay. PLoS One. 2013; 8: e51582. 